\title{
Understanding Corporate Identity in the Office of Automotive Business in Bangkok through Building Users and Design Professionals
}

\author{
Thana Sirijansawang, Prapatpong Upala \\ Multidisciplinary Design Research Program, Faculty of Architecture, \\ King Mongkut's Institute of Technology Ladkrabang (KMITL), Bangkok 10520, Thailand \\ a_thana2000@yahoo.com, a.thana2000@gmail.com
}

\begin{abstract}
The objective of this research is to investigate and understand the difference in physical factors that contribute to cooperate identity which can influence the perception of building users inside five automotive business offices in Bangkok in order to compare the perception level between groups of office building users and design professionals with some evaluations on the physical factors within the offices. The conclusion showed different approaches to interior design that can shape corporate identity and affect the actual building users.
\end{abstract}

Keywords: Corporate Identity, Perception, Physical factor

eISSN 2398-4279 @ 2018. The Authors. Published for AMER ABRA cE-Bs by e-International Publishing House, Ltd., UK. This is an open access article under the CC BY-NC-ND license (http://creativecommons.org/licenses/bync-nd/4.0/). Peer-review under responsibility of AMER (Association of Malaysian Environment-Behaviour Researchers), ABRA (Association of Behavioural Researchers on Asians) and cE-Bs (Centre for EnvironmentBehaviour Studies), Faculty of Architecture, Planning \& Surveying, Universiti Teknologi MARA, Malaysia.

DOI: https://doi.org/10.21834/ajqol.v3i12.154 


\subsection{Introduction}

Visible corporate identity in the physical environment not only plays a significant part in the overall aesthetics but also reflects the cooperate image that can support work values and strongly contribute to credibility management. The identity can also indicate the efficiency in the management peculiar to the company within the automotive businesses (Edmund R. Gray and John M.T. Balmer, 1998). The concept of corporate identity in its designs shall give rise to outstanding, beautiful, and unique area compartmentalization. The corporate identity can practically be seen from the various physical factors such as light factors, colors used for decoration, style of furniture, styles of decoration, area shapes, area continuity, wall decorations and graphic works as well as the use of interior decoration materials in the office space. All these essential physical components can be used to show corporate identity as well as catch the general perception of employees within the organization along with all other parties relevant to the company's image -- whether positively or negatively. The perception level, however, will largely depend on the quality and communication within the particular environment (Seyed, 2014).

This research focuses on the investigation of perception level of physical factors denoting corporate identity between a group of office building users and a group of design professionals who also represent non-members of outsiders to the organization. The two groups will play important roles in the evaluation of the perception of eight physical factors used to communicate corporate identity. Note that these factors are variables from the previous research.

The conclusion of this research will reveal the perception of both building users and professionals, specifically on the congruity and differing opinions on the physical factors that effectively communicate corporate identity and suggestions that can be used as alternative approaches to design and some basic information that can be used to develop design strategies for physical factors that can better communicate cooperate identity in an automotive business office in the future.

\subsection{Literature Review}

The concept of corporate identity Not only do they reflect the personality and uniqueness of an office, but they also denote credibility and the right image which are both considered essential elements to a customer's buying decision process (Mihaela, 2015). As such, physical factors that communicate clearly the cultivated and intended image and corporate identity will impact all appropriate individuals within the organization. And this is especially the case for the building users using the buildings/offices for work and work management as well as customers and relevant individuals from elsewhere (Hashim, 2010).

\subsection{The Components in Communicating Corporate Identity in the Environment}

Such components include the name of the organization, formats, and shapes of symbols, colors, and forms of characters (Edmand R. Gray and John M.T. Balmer, 1998). They can also indicate the differences in status among organizations (Jeremiah lyamabo, 2013), the general perception of outsiders with regards to the quality of the products, the services 
provided, and the leadership roles of the organization in the realm of technology and innovation. And lastly, they can also serve as a reflection of the efficiency of the organization's employees and the manufactured products within the office environment (Mihaela, 2015).

Corporate identity in the environment inside an office that is visible to the eyes does not only reflect working culture of the organization, it also influences the perception and the behaviors often associated with quality of works essential to the possible improvement of the internal management of the organization under the prescribed management strategies (Isabel Olmedo, 2014). By communicating the meaning concerning corporate identity, one can paint a picture of the expected environmental condition within an office through functionality designs, the shape of the area, general atmosphere, and general physical condition, using the available space within the office (Thuckavadee, Nopadon, 2010). These elements, therefore, are critical for communicating the meaning behind corporate identity because they can impact the work of building users (Seyed, 2014).

\subsection{Corporate Identity in Physical Environment}

The visible physical environment within the office which communicates cooperate identity can serve as a reflector of good images for the organization. The image and identity can be expressed through various physical factors including decoration lighting, decoration colors, types of furniture, interior designs, area shapes, space continuity, wall decorations and graphic works, and decoration materials. All of these are physical factors can be used, applied, arranged to communicate corporate identity toward building users and all other relevant individuals (Nopadon, 2011). The outcome will depend in large part on the physical factors used to communicate with the actual building users. Such factors include colors used for decoration, quality of light in work areas. (Rasha, 2011). Also, a graphic design system can also be used to communicate corporate identity using the coherent wall and graphic decorations (Thuckavadee, 2010). These factors can bring about an environment with good internal quality, good organizational image, and the real satisfaction will have a positive impact on the quality of services and products as well as the loyalty of both customers and relevant parties. (Jamaliah, 2014).

\subsection{Physical factors that impact building users}

Previous research has shown the effects of physical factors within office space which affect both employees and building users, whether regarding the general satisfaction or work efficiency -- all of which remain crucial factors for relevant design considerations. Such factors include the general atmosphere within the office space, lighting, and light usage, the suitable degree of temperature, air quality, and the colors used for decoration. Research has proven that all of these factors directly influence the satisfaction level of employees ( $\mathrm{N}$. Kamarulzaman, 2011). Such factors include lighting used for decoration, working with different ceiling heights which negatively affects working, clarity in the work environment, and also the interrelations among personnel within the workplace (Greg R. Oldham, 1983). The main factors that will most likely affect work behaviors and perception are color tones and decoration lighting. The two factors will dramatically affect the satisfaction level of building 
users (Nattha, 2016) with regards to the general atmosphere within the office spaces (Nurlelawati, 2011).

\subsection{Methodology}

\subsection{Data Collection and Sample}

A total of 161 completed questionnaires was returned. Table 1 shows the specific characteristics of the respondents: male (54.03) and female (45.96). The respondents' ages are 21-30 years old (50.93), 31-40 (32.91) and (16.14) for 41-50 years old. The employment period between $1-5$ years is (68.32) on average.

Table 1: Showing Specific Characteristics of Research Sampling Groups

\begin{tabular}{|c|c|c|c|c|c|c|c|c|c|c|c|}
\hline Description & & & & & Auto & tive 0 & e & & & & Total \\
\hline \multicolumn{12}{|l|}{ Gender } \\
\hline - Male & 22 & 71.0 & 14 & 42.4 & 17 & 53.1 & 15 & 45.5 & 19 & 51.4 & 54.03 \\
\hline $\begin{array}{l}\text { - Female } \\
\text { Age }\end{array}$ & 9 & 29.0 & 19 & 57.6 & 15 & 46.9 & 18 & 54.5 & 13 & 35.1 & 45.96 \\
\hline - $21-30$ & 19 & 61.3 & 14 & 42.4 & 10 & 31.3 & 18 & 54.5 & 21 & 56.9 & 50.93 \\
\hline - $31-40$ & 8 & 25.8 & 15 & 45.5 & 9 & 28.1 & 11 & 33.3 & 10 & 27.0 & 32.91 \\
\hline $\begin{array}{l}\text { • 41-50 } \\
\text { Time/Year }\end{array}$ & 4 & 12.9 & 4 & 12.1 & 13 & 40.6 & 4 & 12.1 & 1 & 2.7 & 16.14 \\
\hline $\begin{array}{l}-1-5 \\
\text { years }\end{array}$ & 26 & 83.9 & 25 & 75.8 & 12 & 37.5 & 29 & 87.9 & 18 & 48.6 & 68.32 \\
\hline $\begin{array}{l}5-10 \\
\text { years }\end{array}$ & 5 & 16.1 & 6 & 18.2 & 14 & 43.8 & 3 & 9.1 & 8 & 21.6 & 22.36 \\
\hline $\begin{array}{l}\text { - More } \\
\text { than } 10\end{array}$ & - & - & 2 & 6.1 & 6 & 18.8 & 1 & 3.0 & 6 & 16.2 & 9.31 \\
\hline $\begin{array}{l}\text { Responsibi } \\
\text { lity }\end{array}$ & & & & & & & & & & & \\
\hline $\begin{array}{l}\text { - Chief } \\
\text { Executiv } \\
\mathrm{e}\end{array}$ & - & - & - & - & 1 & 3.1 & - & - & - & - & 0.62 \\
\hline $\begin{array}{l}\text { - Head to } \\
\text { Division }\end{array}$ & 5 & 16.1 & 2 & 6.1 & 3 & 7.4 & 4 & 12.1 & 4 & 10.8 & 11.18 \\
\hline $\begin{array}{l}\text { - Employ } \\
\text { ees }\end{array}$ & 26 & 83.9 & 31 & 93.9 & 28 & 87.5 & 29 & 87.9 & 28 & 75.7 & 88.19 \\
\hline
\end{tabular}

(Source: Author)

Between 5-10 years (22.36) and more than a decade (9.31). Regarding work division, $88.19 \%$ are at officer levels while $11.18 \%$ are at executive levels. Both groups are actual building users. The data collected from the surveys/questionnaires were then compared with the data gathered in another sampling group of design professionals.

\subsection{Methodology}

This report is part of the full-version research which selects sample groups from 4 different types of businesses from a total eight business groups according to the registration database of The Stock Exchange of Thailand. The business categorization can be compared with the corporate classification in other countries (SET data: 2015). The necessary steps taken for 
this research and the subsequent data collection are as follows.

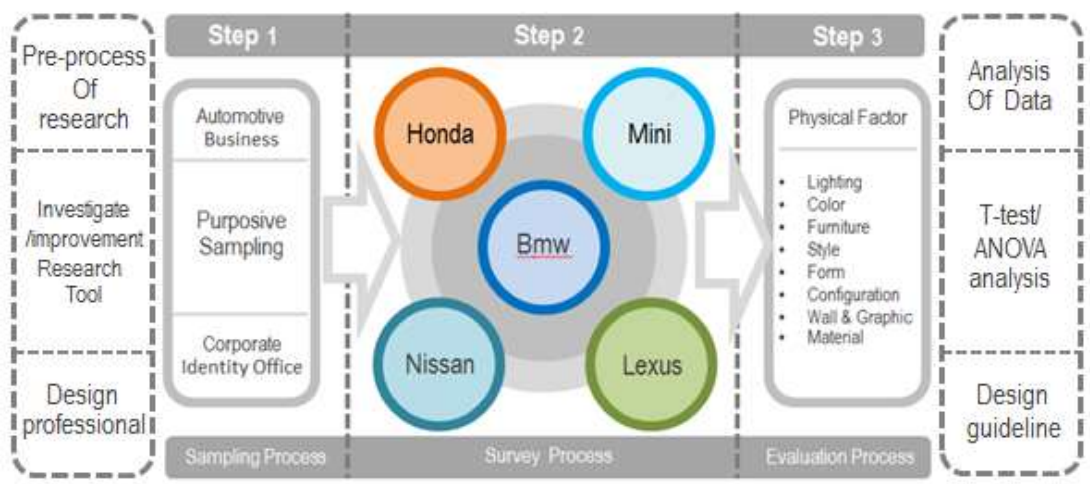

Figure 1: Research Methodology

(Source: Author)

(1) Simple Random Sampling Method. Figure 1 shows the selection of automotive business from a total of 8 industries, and five automotive business offices resulted from the use of purposive sampling method in selecting sampling groups that are in line with the purposes of this research. The sampling groups selection criteria are as follows (1) The interior of the office must use the concept of corporate identity in its space arrangements and designs (2) The working area must not be smaller than 500 square meters and (3) The office must have no less than 50 full-time workers.

(2) Conduct surveys on the physical conditions inside the selected automotive business offices, including those of HONDA, MINI, BMW, NISSAN, LEXUS. The eight physical factors used in the evaluation. Figure 2-6 show the physical conditions within the offices of the sampling groups in this research.

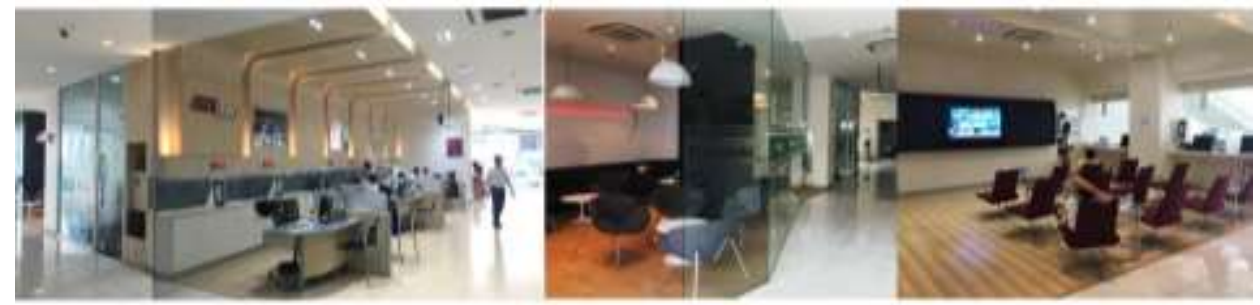

Figure 2: A physical of participant Automotive business group (HONDA) (Source: Author) 


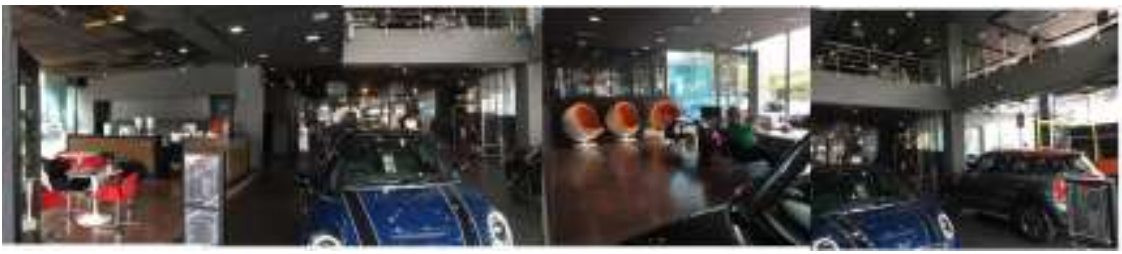

Figure 3: A physical of participant Automotive business group (MINI) (Source: Author)
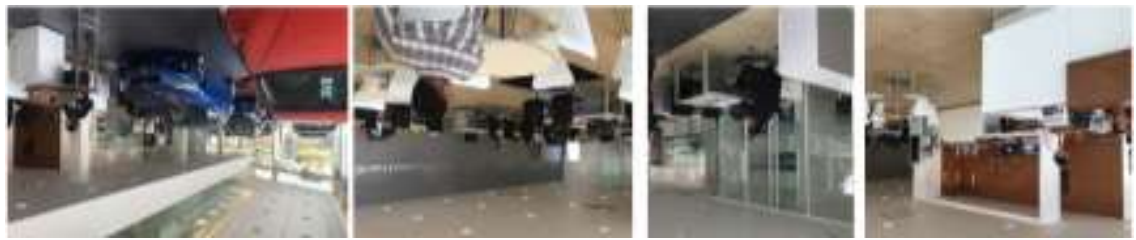

Figure 4: A physical of participant Automotive business group (BMW)

(Source: Author)
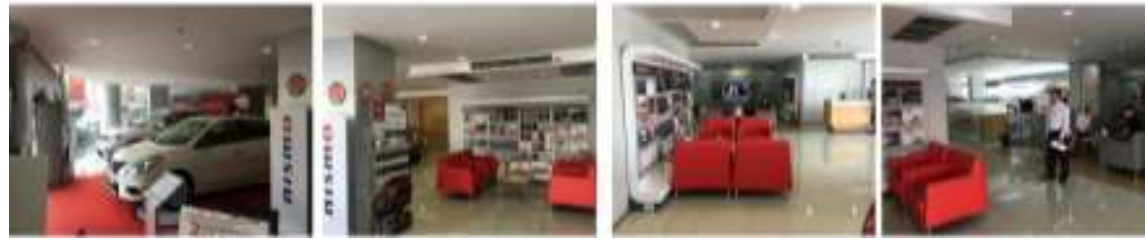

Figure 5: A physical of participant Automotive business group (NISSAN) (Source: Author)
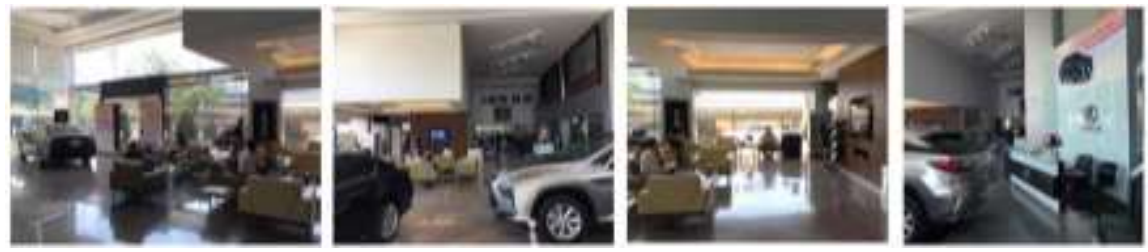

Figure 6: A physical of participant Automotive business group (LEXUS) (Source: Author)

(3) Proceed with fieldwork surveys and data collection. The sampling groups are 161 fulltime employees and 5 Ph.D. level design professionals.

(4) The data was analyzed by SPSS19 program, using the descriptive statistics data to analyze the different demographics from respondents on a 5 -level scale (Likert scale), having ( $1=$ lowest and $5=$ highest) level for the evaluation on the level of Identity as a whole and Physical Variable factors that reflected the 8 physical factors of corporate identity as well as the satisfaction and improvement levels in physical offices. Analysis of 
the experience of variables in this research used statistical T-Test and ANOVA for the Analysis and Summary, recommendations, and setting the level of statistical significance at 95 or 0.05 percent.

\subsection{Measures}

\subsubsection{Independent Variables}

Variables used in this evaluation cover all important factors in designing an office by making use of corporate identity to indicate unique character and distinctive management system (Edmund R. Gray \& John M. T. Balmer, 1998). The particular characteristics and the unique corporate identity are communicated through colors usage, decoration lighting, furniture styles, interior designs, shapes of internal spaces, area continuity, wall decorations and graphic works as well as decoration material (Thuckavadee, Nopadon, 2010) that can all represent the image of the specific workplace. The investigation and modification of tools used in the fieldwork data collection had been achieved with assistance from university professors with a Ph.D. in designs.

\subsubsection{Dependent Variables}

The dependent variables of the perception level of physical factors that communicate corporate identity within automotive business offices in Bangkok can be divided into the following three areas: (1) The overall assessment of corporate identity level in the office environment. In the (2) area is the evaluation of the eight physical factors that communicate corporate identity. Lastly, the (3) area is the evaluation of satisfaction level and the aspects of physical factors communicating corporate identity that must be improved.

\subsubsection{Credibility Analysis}

In Table 2, all coefficients Cronbach's Alpha show high scores for each questionnaire topic, when the data are compared between that of building users and design professionals. The scores are shown in 3 parts, with (1) being the evaluation of identity level in the overall physical condition, $0.866-0.988$ in Research.

\begin{tabular}{|c|c|c|}
\hline \multirow{3}{*}{$\begin{array}{l}\text { Measures Item } \\
\text { Over all office identity level } \\
\text { Physical factor of identity }\end{array}$} & \multicolumn{2}{|c|}{ Participants } \\
\hline & Building Users & Design Professional \\
\hline & 0.866 & 0.988 \\
\hline - Interior Lighting & 0.918 & 0.984 \\
\hline - Interior Color & 0.918 & 0.984 \\
\hline - Style Furniture & 0.926 & 0.984 \\
\hline - Interior Style & 0.929 & 0.989 \\
\hline - Interior form & 0.928 & 0.989 \\
\hline - Configuration & 0.925 & 0.993 \\
\hline - Wall Decoration \& Graphic & 0.943 & 0.966 \\
\hline - Material \& Decoration & 0.929 & 0.995 \\
\hline Satisfaction level/8 Factor & 0.929 & 0.992 \\
\hline Adjustment level/8 Factor & 0.937 & 0.992 \\
\hline
\end{tabular}


Part (2) is the evaluation of the eight physical factors which signify the corporate identity. As shown in the Table below, the Cronbach's Alpha value is relatively high, at (0.918-0.995) with some differences from factor to factor. For Part (3) which is the satisfaction level of building users on the physical factors, the value is $(0.927)$ for building users and $(0.992)$ for design professionals. As for the areas where further improvement is needed, the value is (0.937) for building users and (0.992) for design professionals.

\subsection{Results and Discussion}

\subsection{Comparing the Overall Perception Level of Corporate Identity in Offices among the two different groups of Building Users and Design Professionals}

Data in Table 3 shows the comparison of the overall perception level of corporate identity among the two diverse groups of building users and design professionals, with questions used as the indicators of corporate identity in the visible environment. The signs are directed in the following four areas.

Table 3: Showing the Overall Perception of Corporate Identity in Office Spaces in Automotive Business Companies.

Dependent variables

Over all office Identity level

- Office space is distinctive and beautiful.

- Office space is unique and has the particular model.

- Office space, support and promote the work.

- Office space can reflect the identity of the organization.

Total

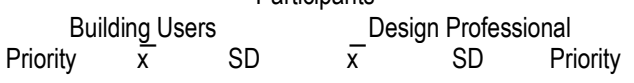

\begin{tabular}{|c|c|c|c|c|}
\hline 2 & $\begin{array}{c}3.70 \\
1\end{array}$ & 0.705 & 3.640 & 0.907 \\
\hline 3 & $\begin{array}{c}3.68 \\
9\end{array}$ & 0.717 & 3.520 & 0.871 \\
\hline & $\begin{array}{c}3.53 \\
4\end{array}$ & 0.758 & 3.760 & 0.969 \\
\hline 1 & $\begin{array}{c}3.80 \\
1\end{array}$ & 0.797 & 3.520 & 0.962 \\
\hline & $\begin{array}{c}3.68 \\
1\end{array}$ & 0.629 & 3.610 & 0.857 \\
\hline
\end{tabular}

(Source: Author)

Data in Table 4 show the scores of the evaluation on the overall perception of corporate identity in the offices among building users, with the highest scores at (3.912) in LEXUS automotive office, whereas at MINI office, the perception score is (3.727) and (3.414) at BMW which is the lowest. On the other hand, for design professionals, the highest score of (4.350) is from MINI office, and 2 locations obtained the score of (3.800). These were the HONDA office and LEXUS office. The scores are quite different from that obtained from the evaluation at NISSAN office, which has the lowest score, at (2.450)

Table 4: Showing the Overall Perception of Corporate Identity in the Offices Among Building Users

Dependent variables and Designs Professionals

Building Users
Participants

Design Professional 
Sirijansawang, T., \& Upala, P. / Asian Journal of Quality of Life (AjQoL), 3(12) Jul / Aug 2018 (p.177-193)

(Over all office identity level) Priority

HONDA

MINI

BMW

NISSAN

LEXUS

$\bar{x}$
3.693
3.727
3.414
3.643
3.912

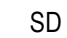

0.597

0.721

0.442

0.496

0.745

(Source: Author) $\bar{x}$

3.800

4.350

3.650

2.450

3.800
SD

0.715

0.5184

0.602

0.512

0.737
Priority

2
1
3
4
2

The data in-depth investigation on the details and the differences in each physical factor show that the average score for LEXUS office is (3.912) for building users and (3.800) for design professionals. The differences in the score result mostly from the high scores from building users in the use of colors in the interior designs of the office, the usage of decoration colors, furniture styles, and decoration styles. Building users also mostly agreed on other factors including the area shapes and space continuity. For BMW office, the evaluation scores are relatively lower, with only (3.414) among building users and (3.650) among design professionals.

\subsection{Comparing the Perception Level of Physical Factors that Communicate Corporate Identity of the Organization}

Table 5: Showing the Perception of Physical Factors in Automotive Business Among Building Users and Design Professionals.

\begin{tabular}{|c|c|c|c|c|c|c|}
\hline \multirow{3}{*}{ Dependent variables } & \multicolumn{6}{|c|}{ Participants } \\
\hline & \multicolumn{3}{|c|}{ Building Users } & \multicolumn{3}{|c|}{ Design Professional } \\
\hline & Priority & $\bar{x}$ & SD & $\bar{x}$ & SD & Priority \\
\hline Physical factor of identity & & & & & & \\
\hline - Interior Lighting & 3 & 3.68 & .724 & 3.45 & .845 & 2 \\
\hline - Interior Color & 1 & 3.80 & .688 & 3.58 & .989 & 1 \\
\hline - Style Furniture & 6 & 3.60 & .719 & 3.28 & .930 & 6 \\
\hline - Interior Style & 2 & 3.72 & .710 & 3.35 & .915 & 5 \\
\hline - Interior form & 6 & 3.60 & .688 & 3.40 & .970 & 4 \\
\hline - Configuration & 5 & 3.61 & .682 & 3.41 & .969 & 3 \\
\hline $\begin{array}{l}\text { - Wall Decoration \& } \\
\text { Graphic }\end{array}$ & 7 & 3.55 & .722 & 3.20 & .828 & 8 \\
\hline - Material \& Decoration & 4 & $\begin{array}{l}3.64 \\
\text { urce: }\end{array}$ & .678 & 3.27 & 1.01 & 7 \\
\hline
\end{tabular}

The data in Table 5 shows the average score for each physical factor from the total of 8 elements. The score for each factor seems to correspond with one another. The average score for HONDA is (3.55) and mostly comes from the color uniqueness (3.73), lighting and area continuity (3.67) with the overall design and decoration of the building that strongly contribute to the firm perception of the corporate identity of HONDA. On the other hand, for MINI office, the data table indicates high average scores from the evaluation. The average score is (3.83) with the score for uniqueness in terms of decoration colors at (4.06), interior designs styles (4.00) and the use of interior decoration materials within MINI office at (3.87) -- all of which can very well reflect the strong perception level of the MINI 
Organization through the three physical factors aforementioned.

Table 6: Showing the Perception of Physical Factors that Communicate Corporate Identity Among Building Users.

\begin{tabular}{|c|c|c|c|c|c|c|c|c|c|}
\hline $\begin{array}{c}\text { Table } \\
\text { Automotiv } \\
\text { e Office }\end{array}$ & 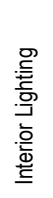 & 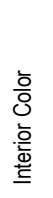 & 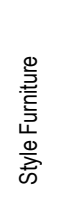 & 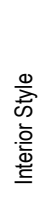 & 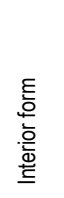 & 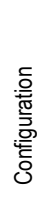 & 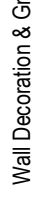 & 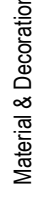 & Total (Average) \\
\hline HONDA & 3.67 & 3.73 & 3.43 & 3.52 & 3.62 & 3.67 & 3.32 & 3.49 & 3.556 \\
\hline MINI & 3.77 & 4.06 & 3.69 & 4.00 & 3.79 & 3.72 & 3.81 & 3.87 & 3.838 \\
\hline BMW & 3.21 & 3.38 & 3.33 & 3.42 & 3.36 & 3.38 & 3.46 & 3.39 & 3.366 \\
\hline NISSAN & 3.60 & 3.90 & 3.80 & 3.79 & 3.50 & 3.61 & 3.58 & 3.72 & 3.687 \\
\hline LEXUS & 4.04 & 3.83 & 3.81 & 3.81 & 3.72 & 3.68 & 3.51 & 3.70 & 3.762 \\
\hline
\end{tabular}

In table 6 BMW office had an average rating of (3.36), with the highest score of (3.46) in wall decorations and graphic designs and (3.42) in interior design styles. Similarly, NISSAN office had an average rating of (3.68), with the highest score of (3.79) in the area of interior design styles and (3.72) for the use of decoration materials. For LEXUS, the average score was (3.76) with the highest score in interior lighting (4.04) and (3.83) for the use of colors in interior decoration as well as (3.81) for the overall interior designs and the styles of the furniture used.

Table 7: Showing the Perception of Physical Factors that Communicate Corporate Identity Among Design Professionals.

\begin{tabular}{|c|c|c|c|c|c|c|c|c|c|c|}
\hline $\begin{array}{c}\text { Table } \\
\text { Automotive } \\
\text { Office }\end{array}$ & 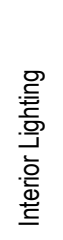 & 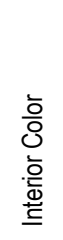 & 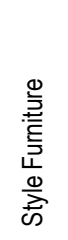 & 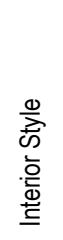 & 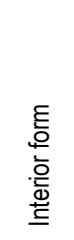 & 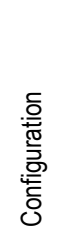 & 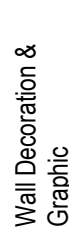 & 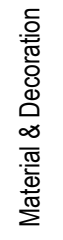 & Total (Average) & Priority \\
\hline HONDA & 3.84 & 3.56 & 3.64 & 3.40 & 3.36 & 3.64 & 3.08 & 3.12 & 3.455 & 3 \\
\hline MINI & 4.16 & 4.24 & 3.92 & 4.28 & 4.40 & 4.08 & 3.92 & 4.36 & 4.170 & 1 \\
\hline BMW & 3.48 & 3.56 & 3.32 & 3.32 & 3.32 & 3.44 & 3.32 & 3.28 & 3.380 & 4 \\
\hline NISSAN & 2.36 & 3.08 & 2.00 & 2.24 & 2.28 & 2.28 & 2.44 & 2.16 & 2.355 & 5 \\
\hline LEXUS & 3.44 & 3.48 & 3.52 & 3.52 & 3.68 & 3.64 & 3.24 & 3.44 & 3.495 & 2 \\
\hline
\end{tabular}

The data from Table 7 shows the evaluation at HONDA office which is relatively outstanding regarding decoration lighting. However, the opinions regarding the furniture styles and area connectivity remain the same at (3.64), with the score for color decoration at (3.56). The more in-depth details of the evaluation and scores for 


\section{each office are shown in Table 8.}

Table 8: Showing the Physical Factors that Communicate Corporate Identity in Each Automotive Business Office

HONDA

Participants

Dependent variables

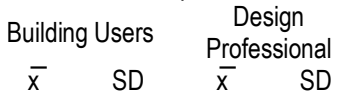

Physical factor of identity

- Interior Lighting

- Interior Color

- Style Furniture

- Interior Style

- Interior form

- Configuration

- Wall Decoration \& Graphic

- Material \&

$\begin{array}{cccc}3.677 & 0.59 & 3.84 & 0.88 \\ & 9 & 0 & 7 \\ 3.735 & 0.70 & 3.56 & 0.99 \\ & 3 & 0 & 3 \\ 3.438 & 0.57 & 3.64 & 1.14 \\ & 8 & 0 & 3 \\ 3.529 & 0.66 & 3.40 & 1.05 \\ & 0 & 0 & 8 \\ 3.625 & 0.65 & 3.36 & 0.97 \\ & 8 & 0 & 3 \\ 3.677 & 0.57 & 3.64 & 0.96 \\ & 8 & 0 & 3 \\ 3.329 & 0.57 & 3.08 & 0.76\end{array}$
Decoratio n

Physical factor of identity

- Interior Lighting

- Interior Color

- Style Furniture

- Interior Style

- Interior form

- Configuration

- Wall Decoration \& Graphic

- Material \&

$$
\text { Decoratio }
$$$$
\mathrm{n}
$$

Physical factor of identity

- Interior Lighting

$\begin{array}{ccc}0.57 & 3.12 & 0.83 \\ 4 & 0 & 1\end{array}$

BMW

$\begin{array}{cccc}3.218 & 0.37 & 3.48 & 0.54 \\ & 4 & 0 & 0 \\ 3.381 & 0.46 & 3.56 & 0.62 \\ & 6 & 0 & 2 \\ 3.331 & 0.47 & 3.32 & 0.46 \\ & 0 & 0 & 0 \\ 3.425 & 0.49 & 3.32 & 0.46 \\ & 7 & 0 & 0 \\ 3.362 & 0.42 & 3.32 & 0.54 \\ & 9 & 0 & 0 \\ 3.381 & 0.48 & 3.44 & 0.65 \\ & 0 & 0 & 4 \\ 3.462 & 0.54 & 3.32 & 0.38 \\ & 3 & 0 & 9 \\ 3.393 & 0.40 & 3.28 & 0.57 \\ & 5 & 0 & 6\end{array}$

LUXUS
MINI

Participants

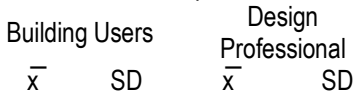

SD

NISSAN

$\begin{array}{cccc}3.60 & 0.82 & 2.360 & 0.498 \\ 0 & 7 & & \\ 3.90 & 0.64 & 3.080 & 1.682 \\ 9 & 4 & & \\ 3.80 & 0.74 & 2.000 & 0.469 \\ 6 & 2 & & \\ 3.79 & 0.58 & 2.240 & 0.589 \\ 3 & 1 & & \\ 3.50 & 0.62 & 2.280 & 0.641 \\ 3 & 6 & & \\ 3.61 & 0.75 & 2.280 & 0.641 \\ 8 & 2 & & \\ 3.58 & 0.72 & 2.440 & 0.973 \\ 1 & 1 & & \\ 3.72 & 0.68 & 2.160 & 0.792 \\ 7 & 5 & & \end{array}$


Sirijansawang, T., \& Upala, P. / Asian Journal of Quality of Life (AjQoL), 3(12) Jul / Aug 2018 (p.177-193)

- Interior Color $\quad 3.837 \quad \begin{array}{cccc}0.66 & 3.48 & 0.54\end{array}$

$\begin{array}{lllll}\text { - Style Furniture } & 3.724 & 0.71 & 3.52 & 0.60\end{array}$

$\begin{array}{lllll}\text { - Interior Style } & 3.816 & 0.83 & 3.52 & 0.57\end{array}$

$\begin{array}{lllll}\text { - Interior form } & 3.729 & 0.81 & 3.68 & 0.83\end{array}$

$\begin{array}{lllll}\text { - Configuration } & 3.686 & 0.77 & 3.64 & 0.86\end{array}$

- Material \&

Graphic $\quad \begin{array}{llll}3.513 & 5 & 0 & 4\end{array}$

$\begin{array}{lcccc}\text { Decoratio } & 3.702 & 0.80 & 3.44 & 1.00 \\ \mathrm{n} & & 9 & 0 & 3\end{array}$

(Source: Author)

\subsection{Comparing the Physical Condition Satisfaction Between Building Users and Design Professionals}
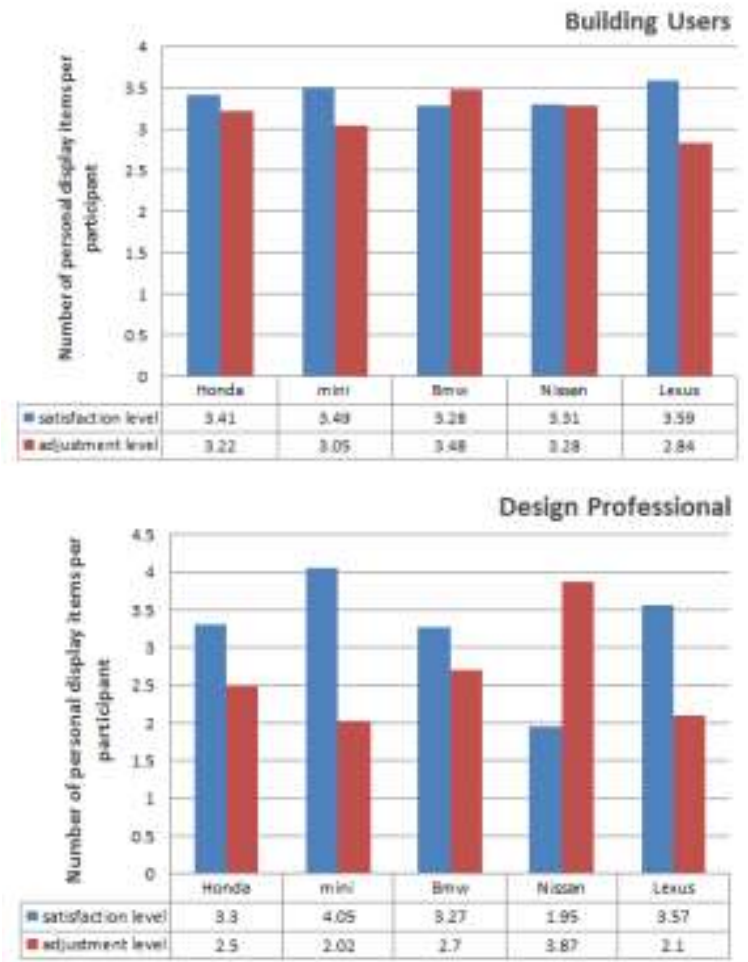

Figure 7: Satisfaction Level and Areas Where Further Improvements Are Needed, as Suggested by Building Users and Design Professionals.

(Source: Author) 
In Figure 7, building users evaluated and rated LEXUS office the lowest in all five offices, with a total score of only (3.59) and (2.84) for further improvement scores. The improvement needed are in the areas of wall decorations and graphic works, with a score of only (3.05). From Figure 7, with design professionals evaluating LEXUS office, the satisfaction rating is (3.57) and (2.10) for things/aspects that must be improved. Improvement is needed in similar areas of wall decorations and graphic artworks, with a score of only (2.60). The data, therefore, corresponds to that of the building users from LEXUS office building.

Table 9: Showing the Satisfaction Level Among Building Users and Design Professionals Pertinent to Automotive Business

Dependent variables

Participants

Physical factor of identity

- Interior Lighting

- Interior Color

- Style Furniture

- Interior Style

- Interior form

- Configuration

- Wall Decoration \& Graphic

- Material \& Decoration

Priority $\bar{x}_{\bar{x}}^{\text {Building Users }}$

SD

$\begin{array}{ccc} & \text { Design Professional } \\ \bar{x} & \text { SD } & \text { Priority }\end{array}$

$\begin{array}{lll}3 & 3.43 & .804 \\ 2 & 3.46 & .806 \\ 5 & 3.40 & .809 \\ 1 & 3.47 & .888 \\ 6 & 3.35 & .801 \\ 1 & 3.47 & .766 \\ 7 & 3.33 & .858 \\ 4 & 3.42 & .834\end{array}$

$\begin{array}{lcl}3.52 & 1.04 & 2 \\ 3.32 & .900 & 3 \\ 3.16 & .850 & 6 \\ 3.24 & 1.051 & 5 \\ 3.28 & 1.021 & 4 \\ 3.28 & 1.100 & 4 \\ 2.92 & .909 & 1 \\ 3.12 & 1.09 & 7\end{array}$

(Source: Author)

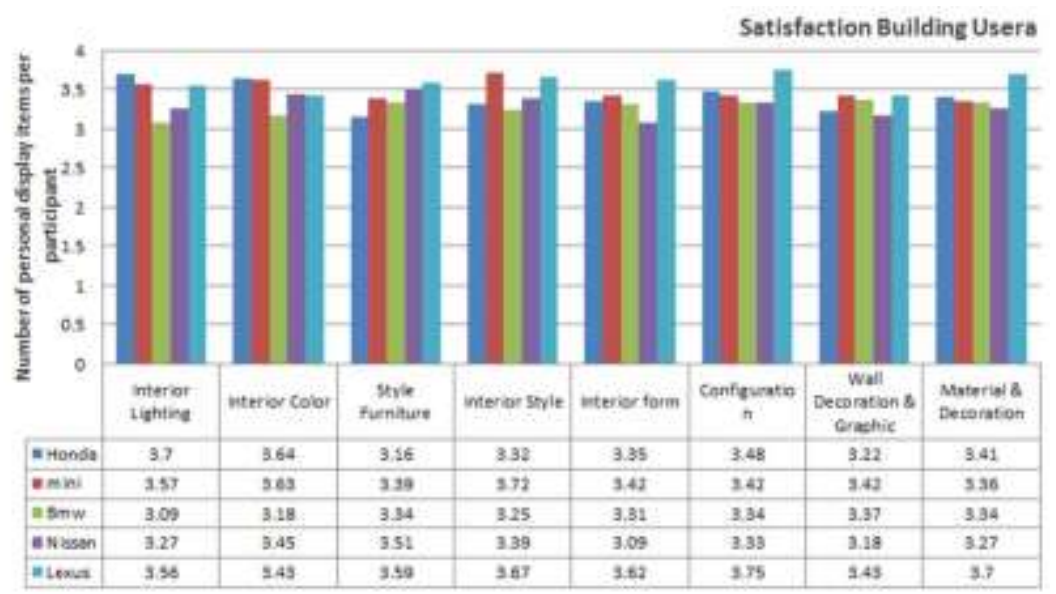

Figure 8: Data Showing the Comparison of Satisfaction Level on the Physical Condition Among Automotive Business Office/Building Users

(Source: Author)

From Figure 7 in BMW office, building users evaluated their satisfaction level in relation the physical factors. The score is (3.28). However, regarding the areas in need of physical 
improvement, the score was (3.48). The data, therefore, indicate the issues/areas where further development are required, including (1) lighting for decoration (2) area continuity (3) usage of decoration materials. At the same time, design professionals evaluated BMW offices and rated their satisfaction level at (3.27). As for the aspects and areas in need of improvement, the score was (2.70). Further improvement is required in 3 areas, including (1) area continuity (3.00) (2) usage of decoration materials (3.00) and (3) wall decorations and graphic artworks (3.00). More accurate data is shown in Figure 11

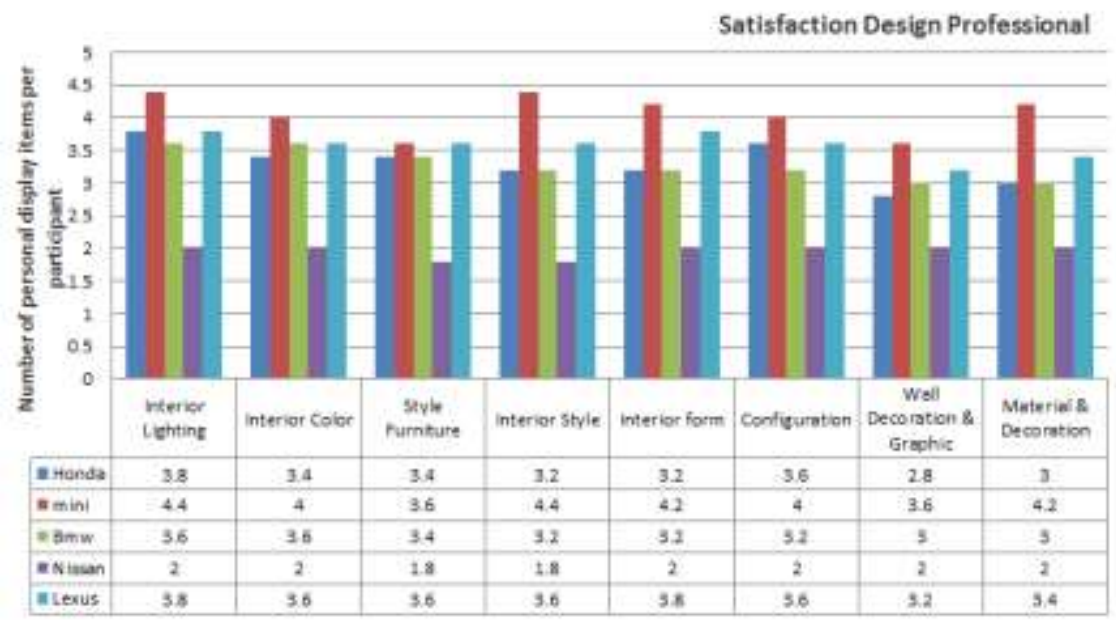

Figure 9: Data Showing the Comparison of Satisfaction Level on the Physical Condition Among Automotive Business Design Professionals

(Source: Author)

For design professionals, the MINI office has the highest satisfaction level at (4.05) In table 9 and Figure 8,9 is consistent with the lowest score in need for physical improvement (2.02). More specifically, the score for the development required in wall decorations and graphic artworks are only (2.40) while the building users express their satisfaction level on the physical conditions inside MINI office at (3.49) and the need for improvement at only (3.05). Most building users want development in the following areas of (1) area shape (3.21), (2) furniture styles (3.18) and (3) area continuity (3.18). Table 10 and Figure 10,11 shows the areas in all five offices that were called for physical improvements by both building users and design professionals. NISSAN building has the lowest physical factors satisfaction level, especially regarding its functionality (1.95), according to design professionals. 
Table 10: Showing the Improvement Needed Pertinent to Automotive Business Among Building Users and Design Professionals

Dependent variables

Physical factor of identity

- Interior Lighting

- Interior Color

- Style Furniture

- Interior Style

- Interior form

- Configuration

Participants

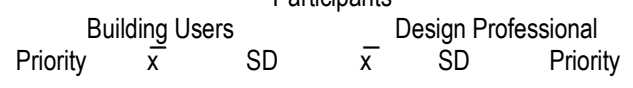

- Wall Decoration \& Graphic

- Material \& Decoration

$\begin{array}{rrrrrr}5 & 3.20 & .949 & 2.36 & 1.113 & 8 \\ 7 & 3.11 & .951 & 2.60 & 1.04 & 5 \\ 4 & 3.21 & 1.002 & 2.64 & 1.036 & 4 \\ 7 & 3.11 & 1.036 & 2.72 & 1.17 & 3 \\ 2 & 3.25 & .957 & 2.52 & 1.15 & 7 \\ 6 & 3.18 & .995 & 2.56 & 1.22 & 6 \\ 1 & 3.27 & .982 & 2.92 & 1.18 & 1 \\ 3 & 3.22 & 1.03 & 2.80 & 1.25 & 2\end{array}$

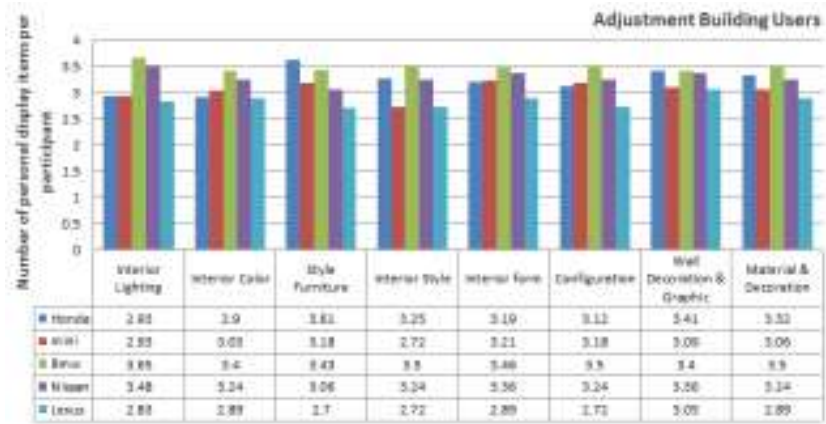

Figure 10: Data comparison by office on the physical aspects that must be improved, according to building users

(Source: Author)

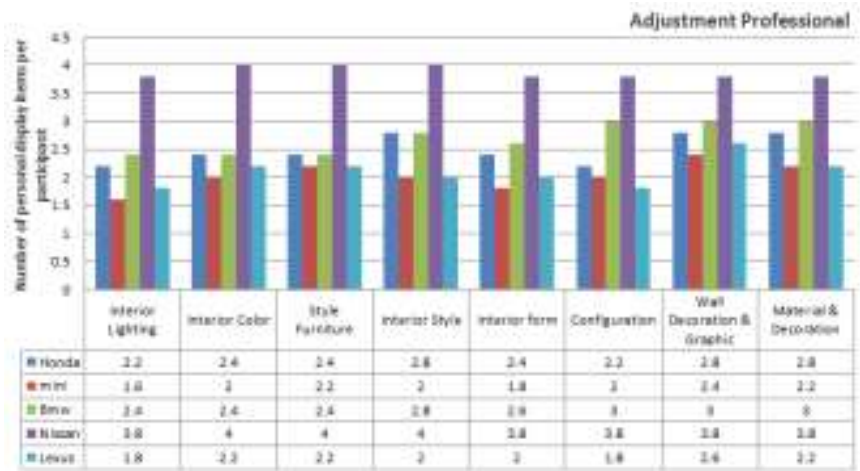

Figure 11: Data comparison by position on the physical aspects that must be enhanced, according to design professionals

(Source: Author) 


\subsection{Conclusion}

The last part of data collected shows the response to the perception of corporate identity and how it can impact physical factors within an office. Data from all five offices have been analyzed together and show the highest perception level among building users in the areas of (1) Physical factor of the color used for decoration (2) Interior decoration style and (3) Interior decoration materials. As for design professionals, their perception level of the physical factors used to communicate corporate identity is prominent in the areas of (1) decoration colors (2) area continuity and (3) shapes of interior spaces, with the lowest scores rated in wall decorations and graphic artworks for both groups of building users and design professionals.

The data shows the importance of design, which will be a decisive factor and an essential reflector for corporate image and identity. What's more, the design must respond to the functionality needs among building users. Some parts of the data collected also show differences in opinions among building users in specific physical factors such as lighting for decoration which can reflect and encourage the aesthetics while retaining the needed functionality among building users or on the use of colors for decoration which can be an indicator and also represent corporate identity. However, difference physical conditions may still affect different levels of identity.

Consequently, those as mentioned above are important factors which can determine the overall designs, decorations and the use of colors or decoration materials. Designers must, therefore, take into account all of the factors discussed, as well as the functionality needs among building users to ensure good designs that are not only aesthetically pleasing but can also effectively communicate the corporate identity. But even more importantly, good designs must incorporate all essential features and translate them into useful functionality.

\section{References}

Edmund R. Gray and John M. T. Balmer. (1998). Managing Corporate Image and Corporate Reputation. Long Range Planning, Vol. 31, No. 5, 695-702.

Greg R. Oldham and Nancy L. Rotchfod. (1983). Relationships between Office Characteristics and Employee Reactions: A Study of the Physical Environment. Administrative Science Quarterly, 28, 524-556.

Hashim Fadzil Ariffin, Mohamad Fahmi Bibon \& Raja Puteri Saadiah Raja Abdullah. (2010). Restaurant's Atmospheric Elements: What the Customer Wants. Procedia - Social and Behavioral Sciences 38, 380-387.

Isabel Olmedo-Cifuentes, Inocencia M. Martinez-LeÓn. (2014). Influence of management style on employee views of corporate reputation. Application to audit firms. Business Research Quarterly 17, 223-241.

Jamaliah Mohd. Yusof, Hasman Abdul Manan, Norzitah Abd. Karim, Nor Akila Mohd. Kassim. (2014). Customer's Loyalty effects of CSR Initiatives. Procedia - Social and Behavioral Sciences 170, 109-119.

Jeremiah lyamabo. (2013). Corporate Identity: Identifying Dominant Elements in CI Models. Journal of Management Research Vol.5, No.3, 28-43.

Mihaela Cornelia Sandu. (2015). Reputation - an Important Element for Automotive Industry Profit?. Procedia - 
Economics and Finance 32, 1038-1041.

Nattha Savavibool, Birgitta Gatersleben, Chumporn Moorapun. (2016). The Effects of Colour in Work Environment: A systematic review. Environment - Behaviour Prodeedings Journal, 262-270.

N. Kamarulzaman, A. A. Saleh, S. Z. Hashim, H. Hashim, A. A. Abdul-Ghani. (2011). An Overview of the Influence of Physical Office Environments towards Employees. Procedia - Engineering 20. 262-268.

Nopadon Sahachaisaeree. (2011). Environmental Simulation and Behavioral Response as Means of Enquiry in Multidisciplinary Design Research Procedure. Procedia - Social and Behavioral Sciences 36, 35-50.

Nurlelawati Ab. Jalil, Rodzyah Mohd Yunus \& Normahdiah S. Said. (2011). Environmental Colour Impact upon Human Behaviour: A Review. Procedia - Social and Behavioral Sciences 35, 54-62.

Rasha Mahmoud Ali El-Zeiny. (2011). The Interior Design of Workplace and its Impact on Employees' Performance: A Case Study of the Private Sector Corporations in Egypt. Procedia - Social and Behavioral Sciences 35, 746-756.

Seyed Abbas Yazdanfar, Ali Akbar Heidari, Negar Aghajari. (2014). Comparison of Architects' and Non-Architects' Perception of Place. Procedia - Social and Behavioral Sciences 170, 690-699.

Thuckavadee Sthienrapapayut, Nopadon Sahachaisaeree. (2010). Corporate strategy as design orientation of spatial function and environmental identity: a case of Kasikorn Bank's branch office in Bangkok. Procedia - Social and Behavioral Sciences 5, 1294-1300. 